\title{
Role of endoplasmic reticulum domains in determining secretion routes
}

\author{
Matthias Seedorf
}

Address: Zentrum für Molekulare Biologie der Universität Heidelberg (ZMBH), DKFZ-ZMBH Alliance, Im Neuenheimer Feld 282, 69120 Heidelberg, Germany

Email: m.seedorf@zmbh.uni-heidelberg.de

Fl000 Biology Reports 2010, 2:77 (doi:10.34I0/B2-77)

This is an open-access article distributed under the terms of the Creative Commons Attribution-Non Commercial License (http://creativecommons.org/licenses/by-nc/3.0/legalcode), which permits unrestricted use, distribution, and reproduction in any medium, provided the original work is properly cited. You may not use this work for commercial purposes.

The electronic version of this article is the complete one and can be found at: http://f1000.com/reports/b/2/77

\begin{abstract}
Distinct domains of the endoplasmic reticulum (ER) can function as entry points into different proteinsorting routes. In addition to using the classical ER-Golgi pathway, one of these unconventional routes utilizes different combinations of machinery of the classical secretory pathway and components of the autophagosomal system.
\end{abstract}

\section{Introduction and context}

Secretion of membrane proteins and the majority of soluble proteins involves translocation through or into the membrane of the endoplasmic reticulum (ER), followed by exportation via coat protein complex II (COPII)-coated vesicles [1]. In yeast, these vesicles exit the ER at evenly distributed sites and fuse directly with dispersed Golgi units. Higher eukaryotes employ the same core machinery for transport but produce spatially organized ER exit sites. COPII vesicles and recycling COPI vesicles form tubular structures that deliver cargo to a centralized Golgi apparatus. In addition to this wellconserved function of the ER as an entry point into the classical secretory pathway, specialized ER domains may function as entry points into more unconventional secretion routes. We are at the beginning of a mechanistic understanding of these alternative transport routes.

\section{Major recent advances}

Most metazoan cell types contain cortical ER domains, which are aligned with the plasma membrane. Ultrastructural analysis in HeLa cells has revealed the presence of cortical ER - thin, ribosome-free structures and precortical ER [2]. Upon ER calcium depletion, these cortical ER domains form ER-plasma membrane contacts, which function in store-operated calcium entry (SOCE).
This signaling process depends on the function of calcium sensors in the ER lumen: the ER-located type I membrane proteins STIM1 (stromal interaction molecule 1) and STIM2 [3]. Recruitment of STIMs to membrane contacts during store depletion involves a dual-targeting mechanism with recognition of phosphatidylinositol phosphate (PIP) species at the cytosolic face of the plasma membrane [4-6] and interaction with the calcium channel in the plasma membrane $[7,8]$. Transient interaction of STIM1 with growing microtubule tips contributes to cortical localization but this process is not required for SOCE [9].

Recognition of PIPs at the cytosolic face of the plasma membrane by integral ER membrane proteins is a conserved mechanism in ER-plasma membrane contact formation. The accumulation of the polytopic yeast membrane protein Ist 2 at cortical ER depends on a basic sorting signal that recognizes $\mathrm{PI}(4,5) \mathrm{P}_{2}[10,11]$. A similar mechanism results in the accumulation of Ist2 at cortical ER domains in mammalian cells and this leads to a large extension of this organelle [5,12]. Formation of cortical ER and accumulation of proteins at cortical ER in mammalian cells depend on COPI and microtubules [12], suggesting that coatomer and its interaction with microtubules play a role in the clustering of proteins in domains of ER membranes. Further studies are necessary in order to 
determine the role of coatomer in the formation of cortical $\mathrm{ER}$, and it remains an open question whether coatomer function contributes to the formation of the abundant cortical ER in yeast as well.

It has recently been proposed that cortical ER domains may function as entry points into unconventional secretion routes. We have suggested that yeast Ist 2 travels directly from cortical ER to the plasma membrane $[13,14]$, but it remains to be solved whether Ist 2 indeed reaches the plasma membrane or whether the protein resides completely in plasma membrane-associated cortical ER. Moreover, this postulated unconventional secretion route is not conserved. Expression of Ist 2 in mammalian cells leads to the induction of cortical ER [5,12], but it has been shown that the protein does not reach the cell surface [5]. However, vesicles that bud off from the cortical ER may bypass the central Golgi in order to reach the neighboring plasma membrane. Such a pathway may play a role in neurons, where the ER forms subsurface cisternae in the soma and extends into dendrites and the axon. This close association between ER and plasma membrane regulates a number of neuronal signaling processes [15] and may play a role in unconventional secretion of locally synthesized proteins. Dendrites contain Golgi outposts that are required for dendritic growth [16] but axons lack these structures. Therefore, in axons, locally translated proteins may travel directly from ER domains to the plasma membrane, bypassing Golgi.

A complete bypass of the Golgi has been described for the secretion of a-integrins in Drosophila during epithelial cell remodeling [17]. This and other transport routes depend on Golgi reassembly stacking protein (GRASP). Deletion of the GRASP homologue GrhA in Dictyostelium discoideum abolishes unconventional secretion of soluble acyl-coenzyme A-binding protein (ACBP) [18], and ACBP-containing vesicles accumulate at the cell cortex with no docking or fusion with the plasma membrane [19]. In $\alpha$-integrin and ACBP secretion, GRASP functions as a cortical organizer of trafficking routes $[17,18,20,21]$.

ACBP is a highly conserved small $(10 \mathrm{kDa})$ protein that binds long-chain acyl-CoA esters with very high affinity and this interaction plays a role in the transport of these molecules [22,23]. Recent work employing an elegant bioassay revealed the first mechanistic insights into unconventional secretion of ACBP $[20,21]$. The morphological development of slime mold depends on the secretion and proteolytic processing of small amounts of the cellular ACBPs [24], and a secreted Acb1 protein fraction from starved yeast cells was sufficient to induce encapsulation of $D$. discoideum $[20,21]$. This secretion of ACBPs requires the function of autophagosomes $[20,21]$, which otherwise mediate the degradation of cytosolic content in response to environmental changes (e.g., starvation). Instead of fusing with the lysosome/vacuole, the ACBP-containing autophagosomes are re-routed to the plasma membrane $[20,21]$. This unconventional secretion occurs independently of the function of many steps of the classical secretory pathway [20] but requires Sec18/NSF, the plasma membrane SNARE Sso1 [20], fatty acyl-CoA generated by peroxisomes [21], multivesicular bodies (MVBs) and the endosomal compartment but not transport from endosomes to vacuoles [20]. ACBPs containing autophagosomes may fuse first with endosomes or MVBs en route to the plasma membrane [20]. However, the precise function of endosomes and MVBs in unconventional secretion of ACBPs remains an open question.

\section{Future directions}

Two exciting questions are how autophagosome-like vesicles specifically recruit ACBPs and where this branch of autophagosome formation occurs. Since ACBPs localize in a ligand-dependent manner to the ER [25], the loaded long-chain acyl-CoA ester may organize ACBP loading and autophagosome formation. This is consistent with the requirement of long-chain acyl-CoA production for unconventional ACBP secretion [21]. The second question addresses the source of the donor membrane for this autophagosome generation. This remains a matter of debate in the autophagy field [26], but it has been suggested that mammalian phagosomes originate from an ER-associated location enriched in PI(3)P [27] and that PI3-kinase and PI3-phosphatase activities determine autophagy initiation $[28,29]$. Electron tomographic analyses support the idea of a direct connection between ER and growing phagosomes [30,31]. Specific PIPs at ER domains in cis and trans may recruit machinery that allows secretion by different mechanisms. Given the high degree of conservation between ACBPs in different species, it is conceivable that human ACBPs use a similar unconventional route to the extracellular space.

\section{Abbreviations}

ACBP, acyl-coenzyme A-binding protein; CoA, coenzyme A; COP, coat protein complex; ER, endoplasmic reticulum; GRASP, Golgi reassembly stacking protein; MVB, multivesicular body; NSF, N-ethylmaleimide-sensitive factor; PIP, phosphatidylinositol phosphate; SNARE, soluble NSF attachment protein receptor; SOCE, storeoperated calcium entry; STIM, stromal interaction molecule. 


\section{Competing interests}

The author declares that he has no competing interests.

\section{Acknowledgments}

Research in the Seedorf laboratory is funded by the German Research Council (DFG).

\section{References}

I. Lee MC, Miller EA, Goldberg J, Orci L, Schekman R: Bi-directional protein transport between the ER and Golgi. Annu Rev Cell Dev Biol 2004, 20:87-I 23.

2. Orci L, Ravazzola M, Le Coadic M, Shen WW, Demaurex N, Cosson P: STIMI-induced precortical and cortical subdomains of the endoplasmic reticulum. Proc Natl Acad Sci U S A 2009, 106: 19358-62.

3. Hogan PG, Lewis RS, Rao A: Molecular basis of calcium signaling in Iymphocytes: STIM and ORAI. Annu Rev Immunol 2010, 28:491-533.

4. Liou J, Fivaz M, Inoue $\mathrm{T}$, Meyer $\mathrm{T}$ : Live-cell imaging reveals sequential oligomerization and local plasma membrane targeting of stromal interaction molecule I after $\mathrm{Ca}^{2+}$ store depletion. Proc Natl Acad Sci U S A 2007, I 04:930I-6.

5. Ercan E, Momburg F, Engel U, Temmerman K, Nickel W, Seedorf M: A conserved, lipid-mediated sorting mechanism of yeast Ist2 and mammalian STIM proteins to the peripheral ER. Traffic 2009, 10:1802-18.

6. Walsh CM, Chvanov M, Haynes LP, Petersen OH, Tepikin AV, Burgoyne RD: Role of phosphoinositides in STIMI dynamics and store-operated calcium entry. Biochem J 2010, 425:I59-68.

7. Park CY, Hoover PJ, Mullins FM, Bachhawat P, Covington ED, Raunser S, Walz T, Garcia KC, Dolmetsch RE, Lewis RS: STIMI clusters and activates CRAC channels via direct binding of a cytosolic domain to Orail. Cell 2009, I36:876-90.

FI000 Factor 6.5 Must Read

Evaluated by Amnon Altman 27 Mar 2009, Timothy Gilbertson 30 Mar 2009, John Cambier II Sep 2009

8. Yuan JP, Zeng W, Dorwart MR, Choi YJ, Worley PF, Muallem S: SOAR and the polybasic STIMI domains gate and regulate Orai channels. Nat Cell Biol 2009, I I:337-43.

9. Grigoriev I, Gouveia SM, van der Vaart B, Demmers J, Smyth JT, Honnappa S, Splinter D, Steinmetz MO, Putney JW Jr, Hoogenraad CC, Akhmanova A: STIMI is a MT-plus-end-tracking protein involved in remodeling of the ER. Curr Biol 2008, I 8: 177-82.

10. Maass K, Fischer MA, Seiler M, Temmerman K, Nickel W, Seedorf M: A signal comprising a basic cluster and an amphipathic \{alpha\}-helix interacts with lipids and is required for the transport of Ist2 to the yeast cortical ER. J Cell Sci 2009, 1 22:625-35.

II. Fischer MA, Temmerman K, Ercan E, Nickel W, Seedorf M: Binding of plasma membrane lipids recruits the yeast integral membrane protein Ist2 to the cortical ER. Traffic 2009, 10:1084-97.

12. Lavieu G, Orci L, Shi L, Geiling M, Ravazzola M, Wieland F, Cosson P, Rothman JE: Induction of cortical endoplasmic reticulum by dimerization of a coatomer-binding peptide anchored to endoplasmic reticulum membranes. Proc Natl Acad Sci U S A 2010, 107:6876-81.

13. Juschke C, Ferring D, Jansen RP, Seedorf M: A novel transport pathway for a yeast plasma membrane protein encoded by a localized mRNA. Curr Biol 2004, I4:406-II.

FI000 Factor 3.0 Recommended

Evaluated by Sebastian Springer 08 Jul 2004
14. Juschke C, Wachter A, Schwappach B, Seedorf M: SECI8/NSFindependent, protein-sorting pathway from the yeast cortical ER to the plasma membrane. J Cell Biol 2005, 169:6I3-22.

FI000 Factor 6.7 Must Read

Evaluated by Rainer Duden 15 Jun 2005, Anne Spang 17 Jun 2005, Catherine Rabouille 30 Jun 2005, Martin Pool I4 Jul 2005

15. Berridge MJ: Neuronal calcium signaling. Neuron 1998, 2 I:I3-26.

16. Ye B, Zhang Y, Song W, Younger SH, Jan LY, Jan YN: Growing dendrites and axons differ in their reliance on the secretory pathway. Cell 2007, 130:717-29.

FI000 Factor 10.3 Exceptional

Evaluated by Lois Weisman 03 Sep 2007, Anne Spang 17 Sep 2007, Michael Kiebler 04 Oct 2007, Bettina Winckler 04 Oct 2007, Y Peng Loh 20 Nov 2007, Irina Majoul 23 Jan 2008

17. Schotman H, Karhinen L, Rabouille C: dGRASP-mediated noncanonical integrin secretion is required for Drosophila epithelial remodeling. Dev Cell 2008, I4:|7|-82.

FI000 Factor 6.4 Must Read

Evaluated by Graham Warren 19 Feb 2008, Robert Parton 04 Mar 2008

18. Kinseth MA, Anjard C, Fuller D, Guizzunti G, Loomis WF, Malhotra V: The Golgi-associated protein GRASP is required for unconventional protein secretion during development. Cell 2007, 130:524-34.

FI000 Factor 3.2 Recommended

Evaluated by Graham Warren 07 Aug 2007, Len Neckers 13 Sep 2007

19. Cabral M, Anjard C, Malhotra V, Loomis WF, Kuspa A: Unconventional secretion of AcbA in Dictyostelium discoideum through a vesicular intermediate. Eukaryot Cell 2010, 9:1009-17.

20. Duran JM, Anjard C, Stefan C, Loomis WF, Malhotra V: Unconventional secretion of Acbl is mediated by autophagosomes. J Cell Biol 2010, 188:527-36.

FI000 Factor 4.8 Must Read

Evaluated by Daniel Klionsky 02 Mar 2010, Brad Marsh 14 Apr 2010

21. Manjithaya R, Anjard C, Loomis WF, Subramani S: Unconventional secretion of Pichia pastoris Acbl is dependent on GRASP protein, peroxisomal functions, and autophagosome formation. J Cell Biol 2010, I88:537-46.

22. Burton M, Rose TM, Faergeman NJ, Knudsen J: Evolution of the acyl-CoA binding protein (ACBP). Biochem J 2005, 392:299-307.

23. Schjerling CK, Hummel R, Hansen JK, Borsting C, Mikkelsen JM, Kristiansen K, Knudsen J: Disruption of the gene encoding the acylCoA-binding protein (ACB I) perturbs acyl-CoA metabolism in Saccharomyces cerevisiae. J Biol Chem 1996, 27I:225 I4-2I.

24. Anjard C, Loomis WF: Peptide signaling during terminal differentiation of Dictyostelium. Proc Natl Acad Sci U S A 2005, I02:7607-II.

25. Hansen JS, Faergeman NJ, Kragelund BB, Knudsen J: Acyl-CoAbinding protein (ACBP) localizes to the endoplasmic reticulum and Golgi in a ligand-dependent manner in mammalian cells. Biochem J 2008, 410:463-72.

26. Hamasaki M, Yoshimori T: Where do they come from? Insights into autophagosome formation. FEBS Lett 20I0, 584:I296-30I.

27. Axe EL, Walker SA, Manifava M, Chandra P, Roderick HL, Habermann A, Griffiths G, Ktistakis NT: Autophagosome formation from membrane compartments enriched in phosphatidylinositol 3-phosphate and dynamically connected to the endoplasmic reticulum. J Cell Biol 2008, I82:685-70I.

FI000 Factor 4.9 Must Read

Evaluated by Michael Roth 27 Aug 2008, Eric Baehrecke 08 Sep 2008, Daniel Klionsky 16 Oct 2008 
28. Vergne I, Roberts E, Elmaoued RA, Tosch V, Delgado MA, ProikasCezanne T, Laporte J, Deretic V: Control of autophagy initiation by phosphoinositide 3-phosphatase Jumpy. EMBO J 2009, 28:2244-58.

29. Taguchi-Atarashi N, Hamasaki M, Matsunaga K, Omori H, Ktistakis NT, Yoshimori T, Noda T: Modulation of local Ptdlns3P levels by the PI phosphatase MTMR3 regulates constitutive autophagy. Traffic 2010, I I:468-78.

30. Hayashi-Nishino M, Fujita N, Noda T, Yamaguchi A, Yoshimori T, Yamamoto A: A subdomain of the endoplasmic reticulum forms a cradle for autophagosome formation. Nat Cell Biol 2009, II:1433-7.

FI000 Factor 6.0 Must Read

Evaluated by Michel Desjardins 23 Dec 2009

3I. Yla-Anttila P, Vihinen H, Jokitalo E, Eskelinen EL: 3D tomography reveals connections between the phagophore and endoplasmic reticulum. Autophagy 2009, 5: I 180-5.

FI000 Factor 6.0 Must Read

Evaluated by Daniel Klionsky 0I Dec 2009 